CZASOPISMO INŻYNIERII LA¿OWEJ, ŚRODOWISKA I ARCHITEKTURY JOURNAL OF CIVIL ENGINEERING, ENVIRONMENT AND ARCHITECTURE

JCEEA, t. XXXIII, z. 63 (4/16), październik-grudzień 2016, s. 315-328

Jan KRUPA ${ }^{1}$

Andrzej MANTAJ ${ }^{2}$

Piotr KOSZELNIK ${ }^{3}$

\title{
GOSPODARKA ENERGETYCZNA A OCHRONA ŚRODOWISKA W OPINII RÓŻNYCH GRUP RESPONDENTÓW - część II
}

\begin{abstract}
Badania miały na celu analizę opinii respondentów w zakresie gospodarki energetycznej, jej oddziaływania na środowisko oraz znaczenia różnych źródeł energii. Materiał badawczy stanowiło 1036 kwestionariuszy ankiet, wypełnionych w okresie październik - grudzień 2015 r. W celu określenia wpływu charakterystyk opisujących respondentów na prezentowane przez nich oceny, podzielono ich na grupy z uwagi na wiek, płeć, miejsce zamieszkania, wykształcenie i deklarowany stopień zainteresowania zagadnieniami z zakresu ochrony środowiska. Do weryfikacji wpływu tych charakterystyk na poglądy ankietowanych osób zastosowano statystyki testu chi-kwadrat. Badania wykazały, że ogólnie niska ocena poziomu wiedzy społeczeństwa dotyczącej problematyki ochrony przyrody była bardziej pesymistyczna u osób z wykształceniem zawodowym i średnim oraz prezentujących niższy poziom zainteresowania ekologią. Jednocześnie osoby te oraz kobiety, osoby starsze oraz absolwenci szkół wyższych, jako bardziej znaczący uznali wpływ człowieka na globalne ocieplenie. Na węgiel kamienny, jako najważniejsze źródła energii w gospodarce kraju, wskazywali mieszkańcy miast oraz osoby mniej zainteresowane problematyką ochrony środowiska, a ta ostatnia grupa osób upatrywała w tym surowcu także najbardziej znaczące źródło energii dla gospodarki podkarpackiej. Spośród rozważanych w opracowaniu źródeł energii odnawialnej praktycznie największy potencjał posiada biomasa, a potrzebę jej szerszego wykorzystywania w gospodarce podnosili mężczyźni, natomiast możliwość zwiększenia jej znaczenia w mieszkalnictwie - absolwenci szkół wyższych.

Ponadto większymi zwolennikami budowy elektrowni atomowej okazali się mężczyźni, osoby młodsze i mieszkańcy wsi.

Przeprowadzona analiza dowodzi często pewnych niezgodności między opiniami respondentów, a rzeczywistym stanem problematyki będącej przedmiotem badań. Stąd niezbędna staje się potrzeba pełniejszego informowania społeczeństwa o stanie i kierunkach rozwoju gospodarki energetycznej w oparciu o rzetelne argumenty.
\end{abstract}

${ }^{1}$ Autor do korespondencji / corresponding author: Jan Krupa, Wyższa Szkoła Informatyki i Zarządzania w Rzeszowie, adres pocztowy e-mail: jkrupa@wsiz.rzeszow.pl

${ }^{2}$ Andrzej Mantaj, Wyższa Szkoła Informatyki i Zarządzania w Rzeszowie

${ }^{3}$ Piotr Koszelnik, Politechnika Rzeszowska im. I. Łukasiewicza, Wydział Budownictwa Inżynierii Środowiska i Architektury 
Słowa kluczowe: emisja zanieczyszczeń, zanieczyszczenie klimatu, konsultacje społeczne, energetyka jądrowa

\section{Wprowadzenie}

W pierwszej części opracowania przedstawiono ogólne profile opinii respondentów w zakresie stanu i wybranych uwarunkowań jakości środowiska związanych głównie z oddziaływaniem gospodarki energetycznej oraz możliwości wykorzystywania różnego rodzaju źródeł energii, przy pominięciu charakterystyk osób, które uczestniczyły w badaniach. Przypuszczać jednak należy, że charakterystyki te mogły mieć duży wpływ na wyrażane przez ankietowanych sądy, co stanowi przedmiot analizy w niniejszej części opracowania.

Osoby, które wzięły udział w badaniach, zamieszkiwały w zdecydowanej większości teren województwa podkarpackiego. Jako determinanty zróżnicowania wypowiedzi respondentów przyjęto ich wiek, płeć, miejsce zamieszkania, wykształcenie i deklarowany poziom zainteresowania ochroną środowiska. W celu określenia istotności powiązań między cechami ankietowanych grup osób a wyrażanymi przez nie ocenami posłużono się statystyką nieparametrycznego testu chi-kwadrat $\left(\chi^{2}\right)$.

\section{Materiał źródłowy i metodyka analizy wyników badań}

Analizę przeprowadzono w oparciu o wypełnione, przez 1036 osób w okresie październik - grudzień 2015 r., kwestionariusze ankiet. Respondenci w zdecydowanej większości byli mieszkańcami województwa podkarpackiego (995), a ponadto województw: lubelskiego (21), małopolskiego (15) oraz śląskiego (5). $\mathrm{W}$ trakcie omawiania badanych problemów podawano rzeczywistą liczbę wypowiedzi dotyczącą danego zagadnienia, ponieważ niektóre kwestionariusze nie zawierały kompletu odpowiedzi.

Opinie były prezentowane głównie poprzez wybór jednego z trzech poziomów akceptacji podanych stwierdzeń, opisujących przedmiot badania, przy czym 1 oznaczało zawsze najwyższy stopień jego aprobaty. Inne wypowiedzi miały charakter zero-jedynkowy i polegały na przyjęciu lub odrzuceniu danego poglądu, co zaznaczano w tablicach poprzez odpowiednio cyfry 1 i 2.

Chcąc uchwycić determinanty wypowiedzi respondentów, dzielono ich kolejno na dwie grupy z uwagi na ich wiek (do i powyżej 25 lat), płeć, miejsce zamieszkania (wieś i miasta), wykształcenie (zawodowe i średnie oraz wyższe) i deklarowane przez nich zainteresowanie ochroną środowiska (małe i duże).W wyniku tego postępowania, zebrane dane należało grupować w dwudzielczych tablicach liczebności o wymiarach $2 \times 2$ lub 2x3. Zakładając niezależność kryteriów stanowiących podstawę konstruowania kolejnych tablic, tj. charakterystyk respondentów oraz ich wyborów odpowiedzi, do weryfikacji tych hipotez 
o niezależności wykorzystano statystyki nieparametrycznego testu chi-kwadrat $\left(\chi^{2}\right)[2]$.

Obliczenie tej statystyki poprzedziło wyznaczenie odpowiadających liczebnościom empirycznym takich liczebności hipotetycznych, które spełniają warunek niezależności. Przyjmując, że $p_{i j}$ jest prawdopodobieństwem przynależności losowo wybranego elementu do klasy $i$ oraz $j \mathrm{z}$ uwagi na opisujące wiersze i kolumny zmienne, a $p_{i}$ i $p_{j}$ są prawdopodobieństwami brzegowymi w tablicy, hipotezę zerową można wyrazić(1):

$$
H_{0}: p_{i j}=p_{i \cdot p_{j}} \text { dla par wskaźników } i, j
$$

a hipotezę alternatywną opisuje:

$$
H_{I}: p_{i j} \neq p_{i . p_{. j}} \text { dla niektórych par wskaźników } i, j
$$

Prawdopodobieństwa brzegowe wyznaczono jako:

$$
\hat{p}_{i j}=n_{i} / n
$$

oraz

$$
\hat{p}_{. j}=n_{. j} / n \text {. }
$$

Wartości oczekiwane, zakładając niezależność zmiennych, obliczymy:

$$
\hat{n}_{i j}=n \hat{p}_{i .} \hat{p}_{. j}=n\left(n_{i .} / n\right)\left(n_{. j} / n\right)=\left(n_{i .} n_{. j}\right) / n .
$$

Statystykę testu chi-kwadrat ustalono na podstawie wzoru:

$$
\chi^{2}=\sum_{i=1}^{k} \sum_{j=1}^{l} \frac{\left(\left|n_{i j}-\hat{n}_{i j}\right|-0,5\right)^{2}}{n_{i j}}
$$

a uwzględnione w liczniku poprawki Yates'a $(-0,5)$ dotyczyły tablic 2x2, w celu przybliżenia dyskretnego rozkładu statystyki testu przez ciągły rozkład chi-kwadrat.

Liczbę stopni swobody określa iloczyn $(k-1)(l-1)$, a hipotezę zerową odrzucano przy poziomie istotności $\alpha=0,05$, gdy $\chi^{2} \geq \chi_{\alpha,(k-1),(l-1)}^{2}$. 


\section{Analiza wyników badań}

Analiza rozkładów opinii respondentów na tle ich charakterystyk dla wszystkich tych zależności, które wykazały statystyczną istotność, zostanie poprzedzona prezentacją cech opisujących respondentów z uwagi na ich wiek, płeć, miejsce zamieszkania, wykształcenie oraz stopień zainteresowania problematyką w zakresie ochrony środowiska, które przedstawiono w tabeli 1.

Około $60 \%$ liczby ankietowanych stanowiły osoby w wieku powyżej 25 lat oraz kobiety, natomiast osób z wykształceniem średnim lub zawodowym było $62,5 \%$, a mieszkańców wsi 55\%. Przeważająca większość, bo ok. $81 \%$ osób wykazywało mniejsze zainteresowanie ochroną środowiska. Tak więc podobne okazały się rozkłady liczebności osób z uwagi na wiek, płeć i wykształcenie, a rozkład ten ze względu na miejsce zamieszkania był zbliżony do poprzednich.

Tabela 1. Charakterystyka respondentów

Table 1. The characteristics of the respondent

\begin{tabular}{|c|c|c|c|c|c|c|c|c|c|c|}
\hline \multirow{3}{*}{$\begin{array}{l}\text { Wyszcze- } \\
\text { gólnienie }\end{array}$} & \multicolumn{10}{|c|}{ Cechy różnicujące respondentów } \\
\hline & \multicolumn{2}{|c|}{ Wiek (lata) } & \multicolumn{2}{|c|}{ Płeć } & \multicolumn{2}{|c|}{ Zamieszkanie } & \multicolumn{2}{|c|}{ Wykształcenie } & \multicolumn{2}{|c|}{$\begin{array}{l}\text { Zainteresowa- } \\
\text { nie ochroną } \\
\text { środow. }\end{array}$} \\
\hline & $\leq 25$ & $>25$ & $\mathbf{K}$ & $\mathbf{M}$ & Wieś & Miasto & $\begin{array}{c}\text { Zaw./ } \\
\text { Śr. }\end{array}$ & $\begin{array}{l}\text { Wyż- } \\
\text { sze }\end{array}$ & Mała & Duża \\
\hline $\begin{array}{c}\text { Liczba } \\
\text { responden- } \\
\text { tów } \\
\end{array}$ & 416 & 620 & 617 & 419 & 570 & 466 & 648 & 388 & 838 & 198 \\
\hline $\begin{array}{c}\text { Odsetek } \\
\text { responden- } \\
\text { tów [ \%] }\end{array}$ & 40,2 & 59,8 & 59,6 & 40,4 & 55,0 & 45,0 & 62,5 & 37,5 & 80,9 & 19,1 \\
\hline
\end{tabular}

W tabeli 2 podano oceny respondentów dotyczące poziomu wiedzy społeczeństwa w zakresie ochrony środowiska oraz wpływu człowieka na globalne ocieplenie. Okazuje się, że osoby z wyższym wykształceniem pozytywniej oceniały wiedzę społeczeństwa dotyczącą ochrony przyrody, aniżeli osoby z wykształceniem zawodowym i średnim. Podobną, ale jeszcze bardziej jednoznaczną w tym względzie opinię miały osoby, które deklarowały większe zainteresowanie problematyką ochrony środowiska. 
Tabela 2. Uwarunkowania ocen poziomu wiedzy społeczeństwa na temat ochrony środowiska i wpływu człowieka na globalne ocieplenie wg odsetek 1036 wypowiedzi [\%]

Table 2. Assessment of the level of public awareness on environmental protection and the human impact on global warming. Opinion of 1,036 respondents [\%]

\begin{tabular}{|c|c|c|c|c|c|c|c|c|c|c|c|c|c|}
\hline \multirow{3}{*}{ Problemy ekologiczne } & \multirow{3}{*}{ 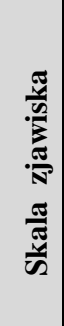 } & \multicolumn{12}{|c|}{ Respondenci i odsetki ich odpowiedzi [\%] } \\
\hline & & \multicolumn{3}{|c|}{ Wiek } & \multicolumn{3}{|c|}{ Płeć } & \multicolumn{3}{|c|}{ Wykształcenie } & \multicolumn{3}{|c|}{$\begin{array}{c}\text { Zaintereso- } \\
\text { wanie ochroną } \\
\text { środowiska }\end{array}$} \\
\hline & & $\stackrel{\text { N }}{\mathrm{V}}$ & $\stackrel{1}{\wedge}$ & 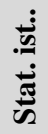 & $\frac{\substack{0 \\
\frac{0}{0}}}{0}$ & 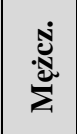 & 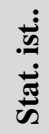 & 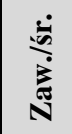 & 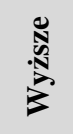 & 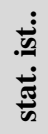 & $\sum_{\sum}^{\frac{\pi}{\pi}}$ & 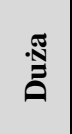 & 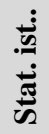 \\
\hline \multirow{3}{*}{$\begin{array}{c}\text { Wiedza społeczeństwa } \\
\text { dotycząca ochrony } \\
\text { środowiska }\end{array}$} & 1 & & & & & & & 9,7 & 13,4 & $* *$ & 7,7 & 25,3 & $* *$ \\
\hline & 2 & & & & & & & 37,5 & 28,1 & & 34,4 & 32,3 & \\
\hline & 3 & & & & & & & 52,8 & 58,5 & & 57,9 & 42,4 & \\
\hline \multirow{3}{*}{$\begin{array}{l}\text { Wpływ człowieka na } \\
\text { globalne ocieplenie }\end{array}$} & 1 & 50,5 & 62,1 & $* *$ & 63,2 & 48,9 & $* *$ & 52,2 & 66,2 & $* *$ & 53,9 & 72,2 & $* *$ \\
\hline & 2 & 32,5 & 24,0 & & 25,9 & 29,6 & & 29,0 & 24,7 & & 29,0 & 20,7 & \\
\hline & 3 & 17,0 & 13,9 & & 10,9 & 21,5 & & 18,8 & 9,1 & & 17,1 & 7,1 & \\
\hline
\end{tabular}

*- istotność przy prawdopodobieństwie $\mathrm{p}=0,05$

**- istotność przy prawdopodobieństwie $\mathrm{p}=0,01$

Źródło: opracowanie własne

Tak więc tylko te dwie charakterystyki różnicowały respondentów pod względem oceny wiedzy społeczeństwa dotyczącej ochrony środowiska. Trudno jednak ustalić, jak własne oceny były ,projektowane” na opinie o innych osobach w zakresie tej problematyki.

Z kolei opinie o stopniu wpływu człowieka na globalne ocieplenie różniły respondentów ze względu na cztery ich charakterystyki. Otóż wpływ ten za większy uważały kobiety oraz osoby starsze, absolwenci szkół wyższych i osoby wykazujące, w ich mniemaniu, większe zainteresowania ochroną środowiska. Pogląd ten powiązany był zapewne $\mathrm{z}$ większą wrażliwością tych osób na problematykę ochrony przyrody, a przez to i z bardziej wyostrzonym dostrzeganiem potrzeb podejmowania $w$ jej interesie aktywnych działań.

$\mathrm{Z}$ przedstawionych $\mathrm{w}$ tabeli 3 ocen stopnia szkodliwości poszczególnych gazów cieplarnianych, z uwagi na skalę ich oddziaływania na zdrowie człowieka wynika, że najczęściej wskazywano dwutlenek węgla, przy czym zagrożenie z jego strony bardziej podkreślały osoby starsze. Kolejnymi gazami cieplarnianymi, względem których opinie o wpływie na zdrowie człowieka różnicowała respondentów, były freony i halony. Mocniej ich siłę oddziaływania podnosiły osoby o większych zainteresowaniach ochroną środowiska, absolwenci szkół wyższych oraz kobiety. Z kolei wyższe zagrożenie ze strony tlenków siarki bardziej podkreślały osoby młodsze. Za największe źródło emisji tlenków siarki uważa się przemysł paliwowo-energetyczny, a dla freonów i halonów, będących przyczyną zmniejszania się stężenia ozonu $\mathrm{w}$ atmosferze i powodujących przez 
to efekt „dziury ozonowej” wykorzystywanie urządzeń gaśniczych, chłodniczych, spieniających, środków w aerozolach oraz rozpuszczalnikach, przy czym w ostatnich latach ogranicza się znacznie ich stosowanie.

Tabela 3. Uwarunkowania ocen szkodliwości gazów cieplarnianych ze względu na skalę ich oddziaływania na zdrowie człowieka wg odsetek 1036 wypowiedzi [\%]

Table 3. Assessment of a harmfulness of greenhouse gases due to the scale of their impact on human health. Opinion of 1,036 respondents [\%]

\begin{tabular}{|c|c|c|c|c|c|c|c|c|c|c|c|c|c|}
\hline \multirow{3}{*}{ Gazy cieplarniane } & \multirow{3}{*}{$\begin{array}{l}\frac{\pi}{4} \\
\frac{\pi}{3} \\
\frac{\pi}{N} \\
\frac{\pi}{\pi} \\
\frac{\pi}{\pi}\end{array}$} & \multicolumn{12}{|c|}{ Respondenci i odsetki ich odpowiedzi [\%] } \\
\hline & & \multicolumn{3}{|c|}{ Wiek } & \multicolumn{3}{|c|}{ Płeć } & \multicolumn{3}{|c|}{ Wykształcenie } & \multicolumn{3}{|c|}{\begin{tabular}{|c|} 
Zaintereso- \\
wanie ochroną \\
środowiska \\
\end{tabular}} \\
\hline & & 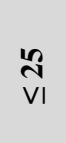 & $\stackrel{2}{\sim}$ & 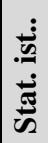 & $\begin{array}{l}\frac{2}{0} \\
\frac{0}{0} \\
1\end{array}$ & 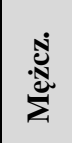 & 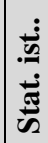 & 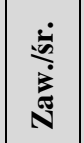 & $\frac{8}{\mathbb{N}}$ & 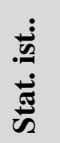 & $\frac{\text { J }}{\text { E }}$ & 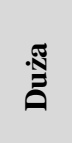 & 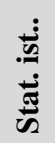 \\
\hline \multirow{2}{*}{ Dwutlenek węgla } & 1 & 25,7 & 33,5 & *** & & & & & & & & & \\
\hline & 2 & 74,3 & 66,5 & & & & & & & & & & \\
\hline \multirow{2}{*}{ Freony i halony } & 1 & & & & 18,5 & 26,7 & ** & 19,3 & 26,0 & $*$ & 20,5 & 27,3 & $*$ \\
\hline & 2 & & & & 81,5 & 73,3 & & 80,7 & 74,0 & & 79,5 & 72,7 & \\
\hline \multirow{2}{*}{ Tlenki siarki } & 1 & 20,4 & 14,0 & $* *$ & & & & & & & & & \\
\hline & 2 & 79,6 & 86,0 & & & & & & & & & & \\
\hline
\end{tabular}

*- istotność przy prawdopodobieństwie $\mathrm{p}=0,05$

**- istotność przy prawdopodobieństwie $\mathrm{p}=0,01$

Źródło: opracowanie własne

W tabeli 4 przedstawiono strukturę opinii dotyczących stopnia potrzeb wykorzystywania tradycyjnych źródeł energii w gospodarce kraju. Mając na uwadze węgiel kamienny, za którego stosowaniem opowiadał się największy odsetek badanych (część 1), częstszymi zwolennikami tego rozwiązania okazali się mieszkańcy miast oraz osoby mniej interesujące się problematyką ochrony środowiska. Ta ostatnia grupa respondentów zdecydowanie częściej wskazywała też potrzebę wykorzystywania węgla brunatnego. Osoby starsze były większymi zwolennikami stosowania gazu, a kobiety - ropy naftowej. Z kolei absolwenci szkół wyższych oraz osoby deklarujące wyższy stopień zainteresowania ochroną środowiska okazały się większymi zwolennikami korzystania z łupków bitumicznych. Za stosowaniem energii jądrowej opowiadali się częściej mężczyźni oraz osoby młodsze. 
Tabela 4. Uwarunkowania ocen dotyczących potrzeb korzystania z źródeł energii przez polską gospodarkę wg odsetek 991 wypowiedzi [\%]

Table 4. Assessments of the needs of the use of energy by the Polish economy. Opinion of 991 respondents [\%]

\begin{tabular}{|c|c|c|c|c|c|c|c|c|c|c|c|c|c|c|c|c|}
\hline \multirow{3}{*}{$\begin{array}{l}\text { Źródła } \\
\text { energii }\end{array}$} & \multirow{3}{*}{ 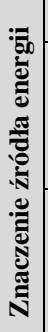 } & \multicolumn{15}{|c|}{ Respondenci i odsetki ich odpowiedzi [\%] } \\
\hline & & \multicolumn{3}{|c|}{ Wiek } & \multicolumn{3}{|c|}{ Płeć } & \multicolumn{3}{|c|}{$\begin{array}{l}\text { Miejsce za- } \\
\text { mieszkania }\end{array}$} & \multicolumn{3}{|c|}{ Wykształcenie } & \multicolumn{3}{|c|}{$\begin{array}{c}\text { Zainteresowanie } \\
\text { ochroną środowi- } \\
\text { ska }\end{array}$} \\
\hline & & 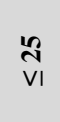 & $\begin{array}{l}\text { an } \\
\wedge\end{array}$ & $\begin{array}{l}\frac{\overrightarrow{2}}{2} \\
\frac{\dot{5}}{\omega}\end{array}$ & $\frac{2}{\stackrel{2}{0}}$ & ¿ूd & 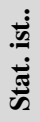 & 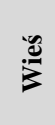 & 产 & 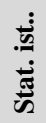 & 离 & 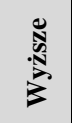 & 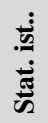 & $\sum^{\frac{\pi}{\pi}}$ & . & 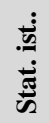 \\
\hline \multirow{3}{*}{$\begin{array}{c}\text { Węgiel ka- } \\
\text { mienny }\end{array}$} & 1 & & & & & & & 46,5 & 50,6 & $*$ & & & & 51,1 & 36,8 & $* *$ \\
\hline & 2 & & & & & & & 29,6 & 21,9 & & & & & 25,9 & 26,9 & \\
\hline & 3 & & & & & & & 23,9 & 27,5 & & & & & 23,0 & 36,3 & \\
\hline \multirow{3}{*}{$\begin{array}{l}\text { Węgiel bru- } \\
\text { natny }\end{array}$} & 1 & & & & & & & & & & & & & 40,9 & 26,4 & $* *$ \\
\hline & 2 & & & & & & & & & & & & & 34,1 & 39,4 & \\
\hline & 3 & & & & & & & & & & & & & 25,0 & 34,2 & \\
\hline \multirow{3}{*}{ Ropa } & 1 & & & & 24,2 & 20,4 & *** & & & & & & & & & \\
\hline & 2 & & & & $\overline{52,0}$ & 42,3 & & & & & & & & & & \\
\hline & 3 & & & & 23,8 & 37,3 & & & & & & & & & & \\
\hline \multirow{3}{*}{ Gaz } & 1 & 36,7 & 49,7 & $* *$ & & & & & & & & & & & & \\
\hline & 2 & 45,5 & 40,0 & & & & & & & & & & & & & \\
\hline & 3 & 17,8 & 10,3 & & & & & & & & & & & & & \\
\hline \multirow{3}{*}{$\begin{array}{l}\text { Energia } \\
\text { jądrowa }\end{array}$} & 1 & 23,8 & 19,6 & * & 19,7 & 23,7 & *** & & & & & & & & & \\
\hline & 2 & 25,4 & 21,0 & & 20,0 & 27,5 & & & & & & & & & & \\
\hline & 3 & 50,8 & 59,0 & & $\overline{60,3}$ & 48,8 & & & & & & & & & & \\
\hline \multirow{3}{*}{$\begin{array}{l}\text { Lupki bitu- } \\
\text { miczne }\end{array}$} & 1 & & & & & & & & & & 21,6 & 31,1 & *** & 20,9 & 42,5 & *** \\
\hline & 2 & & & & & & & & & & 26,1 & 24,3 & & 25,8 & 23,8 & \\
\hline & 3 & & & & & & & & & & 52,2 & 44,7 & & 53,3 & 33,7 & \\
\hline
\end{tabular}

*- istotność przy prawdopodobieństwie $\mathrm{p}=0,05$

**- istotność przy prawdopodobieństwie $\mathrm{p}=0,01$

Źródło: opracowanie własne

W tabeli 5 zebrano dane opisujące opinie dotyczące potrzeby korzystania $\mathrm{z}$ alternatywnych źródeł energii w gospodarce polskiej, spośród których najwięcej było zwolenników kolektorów słonecznych i ogniw fotowoltaicznych (część 1). Pod tym względem zróżnicowanie respondentów polegało, m.in. na tym, że kobiety częściej wskazywały na potrzebę stosowania kolektorów słonecznych, natomiast mężczyźni większe znaczenie przypisywali ogniwom fotowoltaicznym oraz biomasie. $Z$ kolei za szerszym wykorzystywaniem energii wiatru optowały osoby młodsze, a na możliwość powszechniejszego stosowania geotermii i drewna w zaspokajaniu potrzeb energetycznych polskiej gospodarki zwracali uwagę mieszkańcy miast, osoby o wykształceniu zawodowym lub średnim oraz mniej zainteresowane problematyką ochrony środowiska. 
Tabela 5. Uwarunkowania ocen dotyczących potrzeb korzystania z alternatywnych źródeł energii przez polską gospodarkę wg odsetek 968 wypowiedzi [\%]

Table 5. Assessments of the needs of the use of alternative sources of energy for the Polish economy. Opinion of 968 respondents [\%]

\begin{tabular}{|c|c|c|c|c|c|c|c|c|c|c|c|c|c|c|c|c|}
\hline \multirow{3}{*}{$\begin{array}{l}\text { Źródła } \\
\text { energii }\end{array}$} & \multirow{3}{*}{ 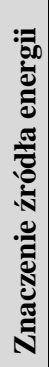 } & \multicolumn{15}{|c|}{ Respondenci i odsetki ich odpowiedzi [\%] } \\
\hline & & \multicolumn{3}{|c|}{ Wiek } & \multicolumn{3}{|c|}{ Płeć } & \multicolumn{3}{|c|}{$\begin{array}{l}\text { Miejsce za- } \\
\text { mieszkania }\end{array}$} & \multicolumn{3}{|c|}{ Wykształcenie } & \multicolumn{3}{|c|}{$\begin{array}{c}\text { Zainteresowanie } \\
\text { ochroną środo- } \\
\text { wiska }\end{array}$} \\
\hline & & $\begin{array}{l}\stackrel{2}{N} \\
\mathrm{VI}\end{array}$ & $\stackrel{1}{N}$ & 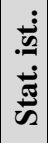 & $\frac{\frac{2}{0}}{\frac{0}{0}}$ & 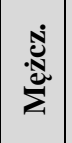 & 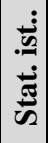 & $\stackrel{n}{3}$ & 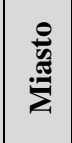 & $\begin{array}{l}\dot{\tilde{n}} \\
\dot{\tilde{E}} \\
\dot{\tilde{\omega}}\end{array}$ & 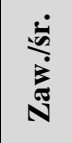 & 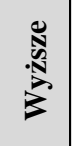 & 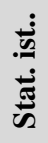 & $\frac{\frac{\pi}{5}}{\sum}$ & 矛 & 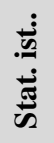 \\
\hline \multirow{3}{*}{$\begin{array}{l}\text { Kolektory } \\
\text { słoneczne }\end{array}$} & 1 & & & & 61,8 & 52,6 & $*$ & & & & & & & & & \\
\hline & 2 & & & & 31,4 & 38,5 & & & & & & & & & & \\
\hline & 3 & & & & 6,8 & 8,9 & & & & & & & & & & \\
\hline \multirow{3}{*}{$\begin{array}{l}\text { Ogniwa foto- } \\
\text { woltaiczne }\end{array}$} & 1 & & & & 44,1 & 48,5 & $*$ & & & & & & & & & \\
\hline & 2 & & & & 47,7 & 39,5 & & & & & & & & & & \\
\hline & 3 & & & & 8,2 & 12,0 & & & & & & & & & & \\
\hline \multirow{3}{*}{$\begin{array}{c}\text { Energia wia- } \\
\text { tru }\end{array}$} & 1 & 36,0 & 29,1 & $* *$ & & & & & & & & & & & & \\
\hline & 2 & 55,4 & 56,8 & & & & & & & & & & & & & \\
\hline & 3 & 8,6 & 14,1 & & & & & & & & & & & & & \\
\hline \multirow{3}{*}{ Geotermia } & 1 & & & & & & & 9,4 & 14,7 & $*$ & 12,4 & 10,8 & $*$ & 12,6 & 8,2 & $*$ \\
\hline & 2 & & & & & & & 58,9 & 54,5 & & 53,3 & 63,0 & & 54,7 & 66,5 & \\
\hline & 3 & & & & & & & 31,7 & 30,8 & & 34,3 & 26,2 & & 32,7 & 25,3 & \\
\hline \multirow{3}{*}{ Biomasa } & 1 & & & & 11,6 & 13,0 & $*$ & & & & & & & & & \\
\hline & 2 & & & & 51,4 & 58,9 & & & & & & & & & & \\
\hline & 3 & & & & 37,0 & 28,1 & & & & & & & & & & \\
\hline \multirow{3}{*}{ Drewno } & 1 & & & & & & & 10,1 & 11,9 & $*$ & 12,0 & 9,1 & $* *$ & 11,7 & 7,7 & $*$ \\
\hline & 2 & & & & & & & 36,8 & 29,0 & & 37,5 & 26,2 & & 34,6 & 27,5 & \\
\hline & 3 & & & & & & & 53,1 & 59,1 & & 50,5 & 64,6 & & 53,7 & 64,8 & \\
\hline
\end{tabular}

*- istotność przy prawdopodobieństwie $\mathrm{p}=0,05$

**- istotność przy prawdopodobieństwie $\mathrm{p}=0,01$

Źródło: opracowanie własne

Charakterystykę ocen respondentów dotyczącą potrzeb korzystania z tradycyjnych źródeł energii przez gospodarkę podkarpacką zaprezentowano $\mathrm{w}$ tabeli 6. Większymi zwolennikami znaczenia węgla kamiennego w tym zakresie częściej okazywały się, tak jak poprzednio, osoby mniej zainteresowane problematyką środowiska. Optowały one również, a wraz z nimi respondenci młodsi wiekiem, za szerszym wykorzystywaniem w tym celu węgla brunatnego. Na znaczenie możliwości powszechniejszego pozyskiwania energii z gazu większą uwagę zwracały kobiety, absolwenci szkół wyższych oraz osoby starsze i bardziej zainteresowane ochroną środowiska. Na możliwości szerszego stosowania w tym celu ropy naftowej wskazywały natomiast kobiety i osoby starsze. Ponad- 
to wśród absolwentów szkół wyższych oraz osób zainteresowanych ekologią powszechniejsze było przekonanie o możliwości szerszego wykorzystania łupków bitumicznych jako źródła energii, co wiąże się z występowaniem tego surowca również na terenie województwa podkarpackiego. $Z$ kolei osoby młodsze i mężczyźni większe znaczenie przypisywali w tym zakresie energii jądrowej.

Tabela 6. Uwarunkowania ocen dotyczących potrzeb korzystania z tradycyjnych źródeł energii przez gospodarkę podkarpacką wg odsetek 987 wypowiedzi [\%]

Table 6 . Assessments of the needs of the traditional energy sources use by the economy of Podkarpackie voivodeship. Opinion 987 respondents [\%]

\begin{tabular}{|c|c|c|c|c|c|c|c|c|c|c|c|c|c|}
\hline \multirow{3}{*}{ Źródła energii } & \multirow{3}{*}{ 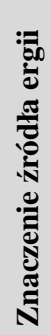 } & \multicolumn{12}{|c|}{ Respondenci i odsetki ich odpowiedzi [\%] } \\
\hline & & \multicolumn{3}{|c|}{ Wiek } & \multicolumn{3}{|c|}{ Płeć } & \multicolumn{3}{|c|}{ Wykształcenie } & \multicolumn{3}{|c|}{\begin{tabular}{|c} 
Zainteresowanie \\
ochroną środo- \\
wiska
\end{tabular}} \\
\hline & & $\begin{array}{l}\mathrm{n} \\
\mathrm{VI}\end{array}$ & $\stackrel{2}{\mathfrak{x}}$ & 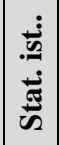 & $\frac{\sqrt{0}}{\frac{0}{0}}$ & 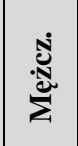 & 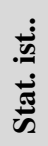 & 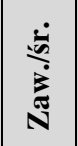 & $\begin{array}{l}\text { N } \\
\text { N } \\
\text { K }\end{array}$ & 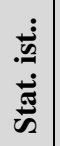 & $\sum^{\frac{\sigma}{\pi}}$ & . & $\begin{array}{l}\dot{\dot{n}} \\
\dot{\vec{\pi}} \\
\dot{\vec{n}}\end{array}$ \\
\hline \multirow{3}{*}{ Węgiel kamienny } & 1 & & & & & & & & & & 48,8 & 31,9 & $* *$ \\
\hline & 2 & & & & & & & & & & 26,2 & 33,5 & \\
\hline & 3 & & & & & & & & & & 25,0 & 34,6 & \\
\hline \multirow{3}{*}{ Węgiel brunatny } & 1 & 39,0 & 28,8 & $* *$ & & & & & & & 35,7 & 21,2 & $* *$ \\
\hline & 2 & 35,3 & 39,2 & & & & & & & & 36,8 & 41,0 & \\
\hline & 3 & 25,7 & 32,0 & & & & & & & & 27,5 & 37,8 & \\
\hline \multirow{3}{*}{ Ropa } & 1 & 27,2 & 29,7 & $* *$ & 30,6 & 25,7 & $* *$ & & & & & & \\
\hline & 2 & 41,1 & 47,3 & & 47,8 & 40,2 & & & & & & & \\
\hline & 3 & 31,7 & 23,0 & & 21,6 & 34,1 & & & & & & & \\
\hline \multirow{3}{*}{ Gaz } & 1 & 35,5 & 52,2 & *** & 48,8 & 40,5 & $* *$ & 41,6 & 52,0 & *** & 42,6 & 58,0 & $* *$ \\
\hline & 2 & 45,1 & 35,9 & & 39,4 & 39,9 & & 43,3 & 33,4 & & 41,7 & 30,9 & \\
\hline & 3 & 19,4 & 11,9 & & 11,8 & 19,6 & & 15,1 & 14,6 & & 15,7 & 11,1 & \\
\hline \multirow{3}{*}{ Energia jądrowa } & 1 & 22,4 & 18,6 & $* *$ & 18,0 & 23,4 & $* *$ & & & & & & \\
\hline & 2 & 27,7 & 20,6 & & 19,9 & 28,8 & & & & & & & \\
\hline & 3 & 49,9 & 60,8 & & 62,1 & 47,8 & & & & & & & \\
\hline \multirow{3}{*}{ Lupki bitumiczne } & 1 & & & & & & & 24,7 & 31,3 & $*$ & 23,9 & 41,0 & $* *$ \\
\hline & 2 & & & & & & & 29,5 & 22,9 & & 27,8 & 23,9 & \\
\hline & 3 & & & & & & & 45,8 & 45,8 & & 48,3 & 35,1 & \\
\hline
\end{tabular}

*- istotność przy prawdopodobieństwie $\mathrm{p}=0,05$

**- istotność przy prawdopodobieństwie $\mathrm{p}=0,01$

Źródło: opracowanie własne

Strukturę opinii dotyczących potrzeb korzystania z alternatywnych źródeł energii $\mathrm{w}$ mieszkalnictwie przedstawiono $\mathrm{w}$ tabeli 7 . Oceny te różnicowały respondentów tylko z uwagi na ich wykształcenie oraz stopień zainteresowania problematyką ochrony przyrody. Otóż okazuje się, że większymi zwolennikami 
stosowania w tym zakresie ogniw fotowoltaicznych były osoby wykazujące większe zainteresowanie ekologią, natomiast na potencjał geotermii, mogący być wykorzystywany na potrzeby mieszkalnictwa, wskazywały osoby deklarujące niższy poziom zainteresowania ochroną środowiska.

Tabela 7. Uwarunkowania ocen dotyczących potrzeb korzystania z alternatywnych źródeł energii w mieszkalnictwie wg odsetek 982 wypowiedzi [\%]

Table 7. Analysis of the needs of the use of alternative energy sources in housing. Opinion of 982 respondents [\%]

\begin{tabular}{|c|c|c|c|c|c|c|c|}
\hline \multirow{3}{*}{ Źródła energii } & \multirow{3}{*}{ 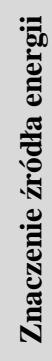 } & \multicolumn{6}{|c|}{ Respondenci i odsetki ich odpowiedzi [\%] } \\
\hline & & \multicolumn{3}{|c|}{ Wykształcenie } & \multicolumn{3}{|c|}{$\begin{array}{c}\text { Zainteresowanie } \\
\text { ochroną środowiska }\end{array}$} \\
\hline & & 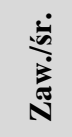 & 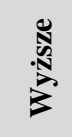 & 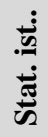 & $\sum_{\Sigma}^{\frac{\Xi}{E}}$ & 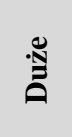 & 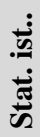 \\
\hline \multirow{3}{*}{ Ogniwa fotowoltaiczne } & 1 & & & & 49,5 & 60,0 & $*$ \\
\hline & 2 & & & & 40,2 & 30,0 & \\
\hline & 3 & & & & 10,3 & 10,0 & \\
\hline \multirow{3}{*}{ Geotermia } & 1 & & & & 9,1 & 6,3 & $*$ \\
\hline & 2 & & & & 52,4 & 63,2 & \\
\hline & 3 & & & & 38,5 & 30,5 & \\
\hline \multirow{3}{*}{ Biomasa } & 1 & 10,5 & 13,3 & $* *$ & & & \\
\hline & 2 & 52,6 & 59,7 & & & & \\
\hline & 3 & 36,9 & 27,0 & & & & \\
\hline \multirow{3}{*}{ Drewno } & 1 & 17,2 & 11,1 & $* *$ & 15,5 & 12,1 & $*$ \\
\hline & 2 & 43,1 & 37,8 & & 42,8 & 34,2 & \\
\hline & 3 & 39,7 & 51,1 & & 41,7 & 53,7 & \\
\hline
\end{tabular}

*- istotność przy prawdopodobieństwie $\mathrm{p}=0,05$

**- istotność przy prawdopodobieństwie $\mathrm{p}=0,01$

Źródło: opracowanie własne

Oceniając te wybory należy stwierdzić, że pozyskiwanie energii elektrycznej poprzez ogniwa fotowoltaiczne jest ciągle mało efektywne, a przez to ich praktyczne zastosowanie ma mniejsze znaczenie, aniżeli energii geotermalnej. Wykorzystanie obu tych źródeł energii wiąże się jednak z potrzebą poniesienia wysokich kosztów inwestycyjnych, a ich atrakcyjność wynika, m.in. z wielkości ich potencjałów oraz braku szkodliwych wpływów na środowisko.

Absolwenci szkół wyższych częściej, aniżeli osoby z wykształceniem zawodowym i średnim, wskazywali na potrzebę korzystania z biomasy, jako źródła energii. Faktem jest, że obecnie, jak i w najbliższej przyszłości jest to zapewne zdecydowanie najbardziej rozpowszechnione alternatywne źródło energii, 
tak z uwagi na proste i efektywne sposoby jej uzyskiwania, jak i formy zastosowania. $\mathrm{Z}$ kolei większymi zwolennikami potencjału energetycznego pozyskiwanego z drewna okazały się osoby z wykształceniem zawodowym i średnim oraz nie wykazujące dużego zainteresowania ochroną przyrody, a więc te mniej uzasadnione opinie korelują głównie z wiedzą tych respondentów.

Ostatni problem rozważany w niniejszym opracowaniu wiąże się ze skłonnością zamiany pieca węglowego na inne źródło ogrzewania oraz akceptacją budowy elektrowni atomowej. Rozkład częstości opinii w tym zakresie zebrano w tabeli 8. Więcej zwolenników zamiany pieca węglowego znaleźć można wśród osób starszych, a także w grupie absolwentów uczelni oraz osób deklarujących większe zainteresowanie ochroną środowiska, przy czym mogą dziwić w tym względzie poglądy osób młodszych, co może jednak wynikać z rzadszego korzystania przez nich z innych rodzajów ogrzewania pomieszczeń. Ponadto nie stwierdzono w tym przypadku różnic między opiniami kobiet i mężczyzn oraz mieszkańcami miast i wsi. Problematyka opalania mieszkań węglem staje się coraz częściej przedmiotem powszechnej dyskusji [1], która podnoszona jest w związku ze smogiem pojawiającym się szczególnie w większych aglomeracjach miejskich, położonych na obniżonym terenie i najczęściej w sąsiedztwie cieków wodnych.

Tabela 8. Uwarunkowania ocen stopnia skłonności do zmiany pieca węglowego na inne źródło ogrzewania oraz akceptacji budowy elektrowni atomowej w Polsce wg odsetek 1036 wypowiedzi [\%]

Table 8. Assessment of the degree of willingness to change coal furnace for other heating source and acceptance of the construction of a nuclear power plant. Opinion of 1,036 respondents [\%]

\begin{tabular}{|c|c|c|c|c|c|c|c|c|c|c|c|c|c|c|c|c|}
\hline \multirow{3}{*}{ Rodzaje działań } & \multirow{3}{*}{ 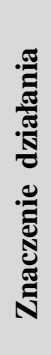 } & \multicolumn{15}{|c|}{ Respondenci i odsetki ich odpowiedzi [\%] } \\
\hline & & \multicolumn{3}{|c|}{ Wiek } & \multicolumn{3}{|c|}{ Płeć } & \multicolumn{3}{|c|}{$\begin{array}{c}\text { Miejsce } \\
\text { zamieszka- } \\
\text { nia }\end{array}$} & \multicolumn{3}{|c|}{$\begin{array}{l}\text { Wyksztal- } \\
\text { cenie }\end{array}$} & \multicolumn{3}{|c|}{$\begin{array}{l}\text { Zaintereso- } \\
\text { wanie } \\
\text { ochroną } \\
\text { środowiska }\end{array}$} \\
\hline & & $\stackrel{n}{N}$ & $\stackrel{2}{N}$ & $\begin{array}{l}\dot{\overrightarrow{2}} \\
\dot{\vec{\pi}} \\
\frac{\pi}{2}\end{array}$ & 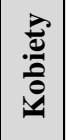 & 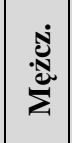 & $\begin{array}{l}\dot{\dot{m}} \\
\dot{\vec{n}} \\
\dot{\vec{n}}\end{array}$ & $\stackrel{\frac{\mathscr{z}}{3}}{3}$ & 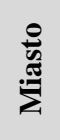 & 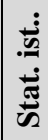 & 这 & 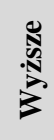 & 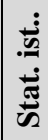 & $\frac{\pi}{\pi}$ & ڤ્ּ & $\begin{array}{l}\dot{\tilde{n}} \\
\dot{\vec{n}} \\
\dot{\tilde{\omega}}\end{array}$ \\
\hline \multirow{3}{*}{$\begin{array}{c}\text { Zamiana pieca } \\
\text { węglowego na } \\
\text { inne źródło }\end{array}$} & 1 & 37,7 & 54,0 & $* *$ & & & & & & & 43,6 & 53,9 & $* *$ & 45,2 & 57,1 & $* *$ \\
\hline & 2 & 36,8 & 28,7 & & & & & & & & 32,6 & 30,9 & & 32,7 & 28,8 & \\
\hline & 3 & 25,5 & 17,3 & & & & & & & & 23,8 & 15,2 & & 22,1 & 14,1 & \\
\hline \multirow{3}{*}{$\begin{array}{c}\text { Akceptacja bu- } \\
\text { dowy elektrowni } \\
\text { atomowej }\end{array}$} & 1 & 25,7 & 20,2 & $* *$ & 19,0 & 27,5 & $* *$ & 23,2 & 21,5 & $* *$ & & & & & & \\
\hline & 2 & 36,5 & 26,6 & & 32,9 & 27,2 & & 27,3 & 34,5 & & & & & & & \\
\hline & 3 & 37,8 & 53,2 & & 48,1 & 45,3 & & 49,5 & 44,0 & & & & & & & \\
\hline
\end{tabular}

*- istotność przy prawdopodobieństwie $\mathrm{p}=0,05$

**- istotność przy prawdopodobieństwie $\mathrm{p}=0,01$

Źródło: opracowanie własne 
Opinie dotyczące wykorzystania elektrowni atomowych w energetyce krajowej są zróżnicowane, a odsetek jego zwolenników maleje w miarę zmniejszającej się odległości miejsca ich zamieszkania od miejsca planowanej lokalizacji siłowni. Antagoniści tego rozwiązania powołują się także na występujące w tym zakresie trendy poza granicami Polski, wskazując na trwający od pewnego czasu proces wygaszania tych elektrowni, np. na terenie Niemiec. Wśród respondentów za wykorzystaniem energii jądrowej częściej opowiadały się osoby młodsze, mężczyźni oraz mieszkańcy wsi.

W innych badaniach dotyczących oceny świadomości i zachowań ekologicznych mieszkańców Polski wykazano, że za najważniejszy sposób redukcji zanieczyszczeń powietrza oraz ochrony środowiska uważano stosowanie odnawialnych źródeł energii (48\% wskazań) oraz wymianę starych pieców węglowych na piece niskoemisyjne (46\%) [3].

\section{Podsumowanie}

Celem opracowania była analiza opinii respondentów w zakresie gospodarki energetycznej z uwzględnieniem jej oddziaływania na środowisko. Materiał badawczy stanowiło 1036 ankiet wypełnionych przez osoby zamieszkujące w zdecydowanej większości teren województwa podkarpackiego. Jako determinanty zróżnicowania wypowiedzi respondentów przyjęto ich wiek, płeć, miejsce zamieszkania, wykształcenie i deklarowany poziom zainteresowania ochroną środowiska. Za podstawę oceny wpływu tych charakterystyk na poglądy badanych osób przyjęto statystykę testu chi-kwadrat.

Biorąc pod uwagę charakterystyki respondentów, ich opinie w zakresie niskiego poziomu wiedzy społeczeństwa dotyczącej problematyki ochrony przyrody była bardziej pesymistyczna u osób z wykształceniem zawodowym i średnim oraz prezentujących niższy poziom zainteresowania ekologią. Ta ostatnia grupa osób oraz kobiety, osoby starsze oraz absolwenci szkół wyższych, jako większy ocenili wpływ człowieka na globalne ocieplenie. Za korzystaniem $\mathrm{z}$ węgla kamiennego, jako najważniejszego źródła energii w gospodarce kraju, opowiadali się mieszkańcy miast oraz osoby mniej zainteresowane problematyką ochrony środowiska, a ta ostatnia grupa osób upatrywała w tym surowcu także najbardziej znaczące źródło energii dla gospodarki podkarpackiej. Z kolei na biomasę, jako praktycznie największe potencjalne źródło energii odnawialnej w gospodarce polskiej wskazywali mężczyźni, a w mieszkalnictwie - absolwenci szkół wyższych. Skłonność zamiany pieca węglowego na inne źródło energii w wyższym stopniu wyrażali absolwenci szkół wyższych, osoby starsze oraz bardziej interesujące się, w swoim mniemaniu, ochroną środowiska, natomiast większymi zwolennikami budowy elektrowni atomowej okazali się mężczyźni, osoby młodsze i mieszkańcy wsi.

Wyniki zaprezentowanej analizy wskazują na duże rozbieżności między opiniami respondentów, a jednocześnie między przedstawionymi ocenami bada- 
nych osób a stanem rzeczywistym problematyki będącej przedmiotem badań. Istnieje więc potrzeba ciągłego i bardziej wielostronnego informowania społeczeństwa o problematyce gospodarki energetycznej, jako jednego ze sposobów poprawy jakości życia, a jednocześnie większej akceptacji odpowiednich w powyższym zakresie działań.

W dobie globalnych i regionalnych problemów środowiskowych, zmian klimatycznych, zmniejszania się bioróżnorodności gatunkowej na Ziemi, koniecznością wydaje się zrównoważony rozwój. Gospodarka zrównoważona jest jednym ze sposobów właściwego rozwoju obszarów wiejskich i miejskich, na których ochrona środowiska przyrodniczego traktowana powinna być priorytetowo. Koncepcja zrównoważonego rozwoju jest jedyną strategią umożliwiającą powstrzymanie degradacji środowiska przyrodniczego, a jej wdrożenie warunkuje trwałość egzystencji społeczeństwa [4,5].

\section{Literatura}

[1] Dec B., Krupa J., Wykorzystanie odnawialnych źródeł energii w aspekcie ochrony środowiska, [w:] Ochrona środowiska w aspekcie zrównoważonego rozwoju społeczno-gospodarczego Pogórza Dynowskiego, (red.) J. Krupa, T. Soliński, Wyd. Związek Gmin Turystycznych Pogórza Dynowskiego, Dynów 2012, s. 55-83.

[2] Jóźwiak J., Podgórski J., Statystyka od podstaw, PWE, Warszawa1998, s. 358-362.

[3] Kachaniak D., Skrzyńska J., Trząsalska A., Badanie świadomości i zachowań ekologicznych mieszkańców Polski, Raport TNS Polska dla Ministerstwa Środowiska, Warszawa listopad 2014, na podstawie: https://www.mos.gov.pl.pdf (dostęp: 16-06-2016).

[4] Krupa J., Działania proekologiczne w turystyce szansą na jej zrównoważony rozwój, Zeszyty Naukowe serii; Turystyka i rekreacja, Z. 13(1), Wyższa Szkoła Turystyki i Języków Obcych, Warszawa 2014, s. 5-23.

[5] Snarski S. J., Rozwój turystyki zrównoważonej w kompleksie przyrodniczokrajobrazowym Natura 2000 w Hackach, Zeszyty Naukowe Uniwersytetu Szczecińskiego, Nr 782, „Ekonomiczne Problemy Turystyki”, Nr 1(21), Szczecin 2013, s. 79-91.

\section{ENERGY MANAGEMENT AND ENVIRONMENTAL PROTECTION IN THE OPINION OF THE VARIOUS CATEGORIES OF RESPONDENTS - Part II}

\section{S u m m a r y}

The study aimed to analyze the respondents' opinion in the field of energy-flux density, its impact on the environment and the importance of different sources of energy. The research material consisted of 1,036 questionnaires, filled in the period October - December 2015. In order to determine the effect of the characteristics that describe the respondents presented their assessment, divided into groups because of their age, gender, place of residence, education and the declared level of interest in issues of environmental concerns. To verify the impact of these characteristics 
on the views of people surveyed used statistics chi-square test. Studies have shown that the generally low assessment of the level of public awareness on the problems of conservation was more pessimistic in people with vocational and secondary education as well as presenting a lower level of interest in ecology. At the same time these people and women, elderly people and university graduates, as more significant recognize human impact on global warming. On coal as the main energy source in the country's economy, they pointed urban residents and people less concerned with environmental protection, and the latter group of people saw in the raw material is also the most important source of energy for the Podkarpackie Voivodeship economy. Among considered in the development of renewable energy sources practically the biggest potential has biomass and the need for its wider use in the economy raised men, and the possibility to increase its importance in housing - graduates. In addition, the larger supporters of the construction of a nuclear power plant turned out to be men, younger people, and rural residents. The analysis shows often inconsistencies between the opinions of the respondents, and actual issues of interest. Hence the imperative felt the need to inform the public about the status and development of the energy economy based on sound arguments.

Keywords: emissions of pollutants, climate pollutants, public consultation, nuclear power energy

DOI:10.7862/rb.2016.276

Przestano do redakcji: 17.10.2016 $r$.

Przyjęto do druku: 20.12.2016 $r$. 